17. Padua L, Padua R, LoMonaco M, Aprile I, Tonali P, for the Italian CTS Study Group. Multiperspective assessment of carpal tunnel syndrome. A multicenter study. Neurology 1999;53: 1654-1659.

18. Mondelli M, Giacchi M, Federico A. Requests for electromyography from general practitioners and specialists: critical evaluation. Ital J Neurol Sci 1998;19:195-203.

19. Roquelaure Y, Mechali S, Dano C, et al. Occupational and personal risk factors for carpal tunnel syndrome in industrial workers. Scand J Work Environ Health 1997;23:364-369.

20. Tanaka S, Wild DK, Seligman PJ, Halperin WE, Behrens VJ, Putz-Anderson V. Prevalence and work-relatedness of self- reported carpal tunnel syndrome among U.S. workers: analysis of the Occupational Health Supplement data of 1988 National Health Interview Survey. Am J Ind Med 1995;27: 451-470.

21. Tanaka S, Wild DK, Cameron LL, Freund E. Association of occupational and non-occupational risk factors with the prevalence of self-reported carpal tunnel syndrome in a national survey of the working population. Am J Ind Med 1997;32: $550-556$.

22. Abbas MA, Afifi AA, Zhang ZW, Kraus JF. Meta-analysis of published studies of work-related carpal tunnel syndrome. Int J Occup Environ Health 1998;4:160-167.
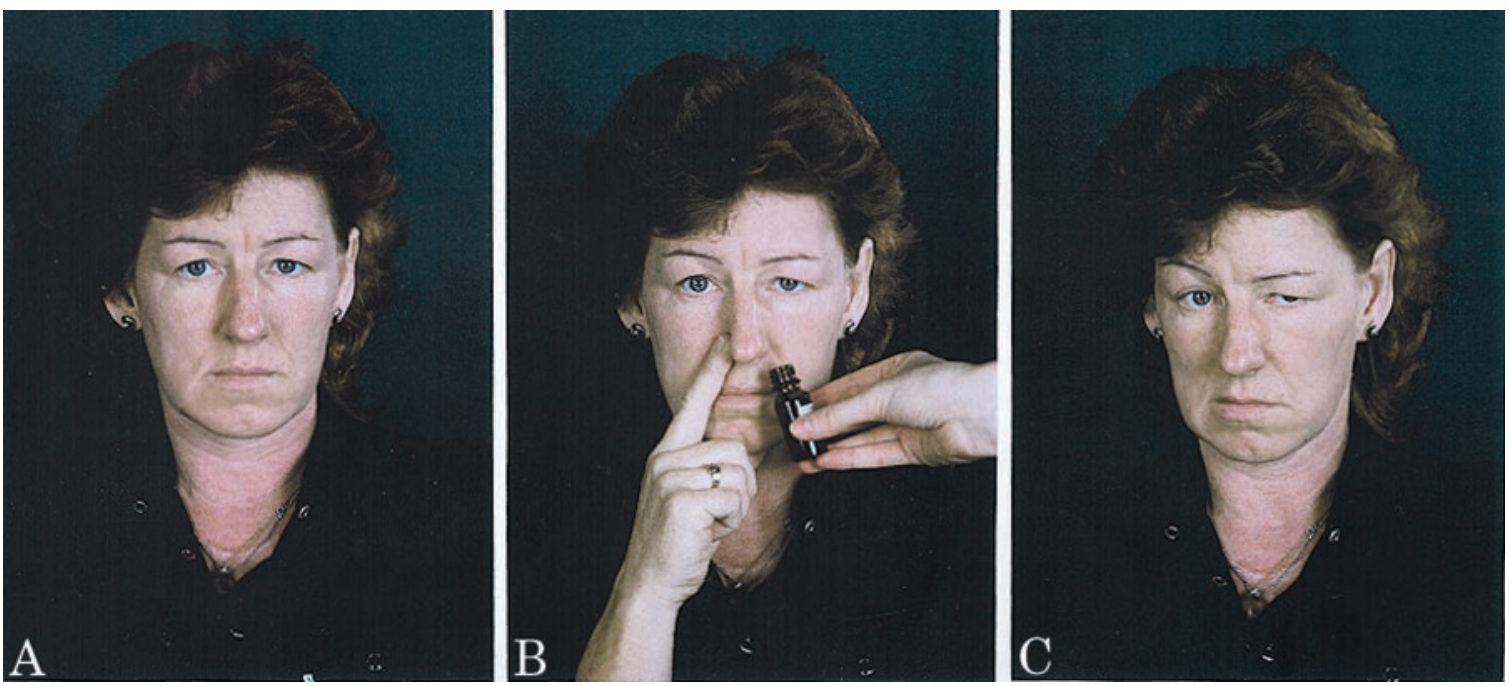

Figure. Patient before (A), during nasal exposure with ammonium chloride (B), and 2 minutes after exposure (C).

\section{Nasally triggered headache}

Kerstin Irlbacher, MD, Bernd-Ulrich Meyer, MD, Berlin, Germany

A 42-year-old woman who had a history of left-sided partial choanal atresia, surgically corrected at the age of 2 , had frequent episodes of an intense left-sided headache over an 18-year period. The pain was felt deep in and around the eye, and radiated into the forehead, temple, and cheek. Each headache episode was triggered by inhalation of substances irritating the nasal mucosa, such as acetone, ammonia, or scouring agents, and lasted, if untreated, for several hours. The headache was always preceded by a swelling of the left side of her face. Clinical neurologic examination, cranial MRI, electroencephalography, and electrically elicited blink reflexes were unremarkable. Exposure of the left nostril (figure, B) to ammonium chloride was stereotypically followed by edema of the left eyelid (after 2 minutes), conjunctival injection (after 3 minutes), lacrimation, rhinorrhea, hemifacial edema (figure, C), and after 10 minutes by attacks of excruciating headache. Swelling and headache lasted up to 10 minutes after inhalation of oxygen or 20 minutes after IV corticosteroids.

This case suggests that the trigeminal system can play a major role in headache, probably associated with increased trigeminal afferent activity from the nasal muscosa. ${ }^{1}$ The role of trigeminal afferent activity is also emphasized by a case with short lasting unilateral neuralgiforme headache with conjunctival injection and tearing syndrome triggered by speaking, chewing, and touching the face. ${ }^{2}$

1. Ottaviani F. Centro-peripheral etiopathogenesis of primary headache triggered nasally. Ital J Neurol Sci 1995;16:35-39.

2. Ertsey C, Bozsik J, Jelencsik AI. A case of SUNCT syndrome with neurovascular compression. Cephalalgia 2000;20:325. 


\title{
Neurology
}

\author{
Nasally triggered headache \\ Kerstin Irlbacher and Bernd-Ulrich Meyer \\ Neurology 2002;58;294 \\ DOI 10.1212/WNL.58.2.294
}

This information is current as of January 22, 2002

\section{Updated Information \&} Services

\section{References}

Citations

Subspecialty Collections

Permissions \& Licensing

Reprints including high resolution figures, can be found at: http://n.neurology.org/content/58/2/294.full

This article cites 2 articles, 0 of which you can access for free at: http://n.neurology.org/content/58/2/294.full\#ref-list-1

This article has been cited by 1 HighWire-hosted articles: http://n.neurology.org/content/58/2/294.full\#\#otherarticles

This article, along with others on similar topics, appears in the following collection(s):

All Epilepsy/Seizures

http://n.neurology.org/cgi/collection/all_epilepsy_seizures

Encephalitis

http://n.neurology.org/cgi/collection/encephalitis

Vasculitis

http://n.neurology.org/cgi/collection/vasculitis

Information about reproducing this article in parts (figures,tables) or in its entirety can be found online at:

http://www.neurology.org/about/about_the_journal\#permissions

Information about ordering reprints can be found online:

http://n.neurology.org/subscribers/advertise

Neurology ${ }^{\circledR}$ is the official journal of the American Academy of Neurology. Published continuously since 1951, it is now a weekly with 48 issues per year. Copyright . All rights reserved. Print ISSN: 0028-3878.

Online ISSN: 1526-632X.

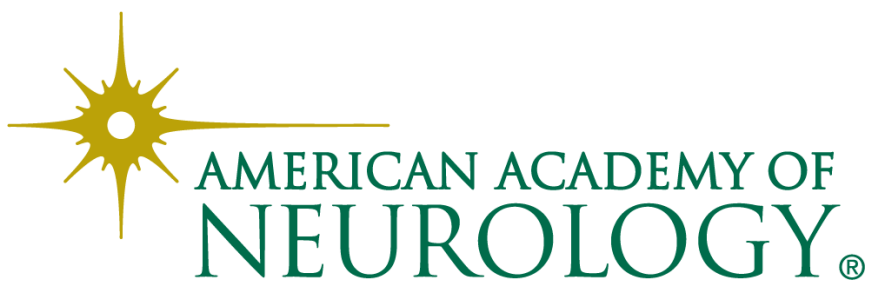

